\title{
Komitmen Organisasi pada Dosen Generasi Milenial
}

\author{
Reza Lidia Sari
}

Fakultas Psikologi Universitas Airlangga, Surabaya - Indonesia

\begin{abstract}
In Human Resource Management, workers from the millennial generation, including those working as lecturers in Indonesia, are often studied with regard to their low level of organizational commitment. Millennial lecturers are often faced with various challenges that can trigger them to decide to quit their jobs and leave the college. This research aimed to discover the factors influencing millennial lecturers' organizational commitment. The instruments used were the Organizational Commitment Scale, Job Satisfaction Survey, and Professional Commitment Scale. The respondents were 123 lecturers from 10 universities in Padang, Jakarta, and Bali, who were selected using purposive sampling technique. The analysis method used was a multiple regression analysis. The research findings showed that job satisfaction and professional commitment, to be exact, their satisfaction with supervisors, professional commitment continuance and normative professional commitment had a significant impact on these lecturers' organizational commitment. The result of this study delivers important implications to universities in managing their millennial lecturers so that they can improve their organizational commitment.
\end{abstract}

Keywords: job satisfaction; lecturer; millennial; organizational commitment; professional commitment

\begin{abstract}
Abstrak: Dalam Manajemen Sumber Daya Manusia, Generasi Milenial, termasuk mereka yang bekerja sebagai dosen di Indonesia, sering diteliti dalam kaitannya dengan komitmen organisasi mereka yang rendah. Dosen milenial sering dihadapkan dengan berbagai tantangan yang dapat memicu mereka untuk memutuskan berhenti dari profesi dosen dan keluar dari perguruan tinggi. Oleh karena itu, penelitian ini bertujuan untuk menemukan faktor-faktor yang memengaruhi komitmen organisasi pada dosen milenial. Alat ukur yang digunakan adalah Skala Komitmen Organisasi, Survei Kepuasan Kerja, dan Skala Komitmen Profesi. Responden penelitian yaitu 123 dosen milenial dari 10 perguruan tinggi yang ada di Padang, Jakarta, dan Bali yang dipilih dengan menggunakan teknik purposive sampling. Metode statistik yang digunakan adalah analisis regresi berganda. Hasil penelitian menunjukkan bahwa kepuasan kerja dan komitmen profesi memiliki pengaruh yang signifikan terhadap komitmen organisasi. Secara lebih spesifik, kepuasan terhadap atasan, komitmen profesi kontinuans, serta komitmen profesi normatif memiliki pengaruh signifikan terhadap komitmen organisasi dosen milenial. Hasil penelitian ini memiliki implikasi penting bagi perguruan tinggi dalam pengelolaan dosen Generasi Milenial agar mereka dapat meningkat komitmen organisasinya.
\end{abstract}

Kata Kunci: kepuasan kerja; dosen; milenial; komitmen organisasi; komitmen profesi

Corresponding Author: Reza Lidia Sari (e-mail: rezalidiasari@psikologi.unair.ac.id). Departemen Psikologi Industri dan Organisasi Fakultas Psikologi Universitas Airlangga. Kampus B UNAIR JI. Airlangga No.4-6, Gubeng, Surabaya 60284. 


\section{Pendahuluan}

Generasi Milenial adalah orang-orang yang lahir pada rentang tahun 1977 sampai 1994 (Hawkins \& Mothersbaugh, 2010). Generasi ini tumbuh bersama berkembangnya teknologi sehingga mereka menjadi mahir dalam mengakses informasi dengan cepat menggunakan teknologi (Angeline, 2011). Teknologi membantu kerja menjadi lebih efektif dan efisien, namun di sisi lain, hal ini juga membuka ruang kesempatan yang luas bagi Generasi Milenial untuk mendapatkan pengetahuan tentang kondisi di luar organisasi tempat mereka bekerja. Mereka bisa menemukan informasi tentang organisasi lain yang mereka anggap lebih sesuai dengan minat mereka dan lebih dapat memenuhi harapan mereka (Salahudin, Alwi, Baharuddin, \& Samad, 2016). Kecenderungan Generasi Milenial yang menyukai tantangan dan ingin terus mempelajari hal baru menjadikan mereka sebagai job hoppers, sampai mereka mendapatkan pekerjaan yang mereka anggap baik dan sesuai dengan minat dan harapan mereka (Filiana, 2016).

Saat ini Generasi Milenial sering menjadi sorotan dalam manajemen Sumber Daya Manusia (SDM) karena mereka cenderung memiliki komitmen organisasi yang lebih rendah dibandingkan generasi sebelumnya (Trapero, Villa-Castaño, Parra, \& García, 2017). Survey yang dilakukan oleh Sheahan (2009) di wilayah Asia Pasifik menunjukkan bahwa Generasi Milenial memiliki masa kerja yang lebih singkat dibandingkan generasi-generasi sebelumnya, yaitu Generasi Milenial memiliki masa kerja rata-rata 18 bulan, sementara Generasi X (lahir pada tahun 1965-1976) dan Generasi Baby Boom (lahir pada tahun 1946-1964) adalah empat tahun. Mereka mudah memutuskan untuk meninggalkan organisasi saat merasa tidak menemukan kecocokan antara apa yang diharapkan dengan apa yang organisasi berikan. Mereka juga sering dikenal sebagai generasi instant karena cenderung tidak sabar dan ingin mencapai tujuannya dengan sesegera mungkin (Kim, Knight, \& Crutsinger, 2009).

Komitmen organisasi didefinisikan sebagai kondisi psikologis yang mengkarakteristikkan hubungan individu dengan organisasi dan memiliki implikasi terhadap keputusan individu tersebut untuk melanjutkan atau tidak melanjutkan keanggotaannya dalam organisasi (Meyer \& Allen, 1991). Menurut Meyer dan Allen (1997) komitmen organisasi ini terdiri dari tiga komponen yaitu: afektif, kontinuans, dan normatif. Komitmen organisasi afektif didefinisikan sebagai keterikatan emosional dan pengidentifykasian individu dengan organisasi tempat ia bekerja serta keterlibatannya dalam organisasi tersebut (Meyer \& Allen, 1997). Selanjutnya, komitmen organisasi kontinuans diartikan sebagai kesadaran akan biaya untung dan rugi yang akan diterima individu sebagai implikasi dari keputusannya meninggalkan organisasi (Meyer \& Allen, 1997). Terakhir, komitmen organisasi normatif dimaknai sebagai perasaan kewajiban yang dirasakan oleh individu untuk meneruskan keanggotaannya dalam organisasi (Meyer \& Allen, 1997). Menurut Meyer dan Allen (1991) ada perbedaan motif yang mendasari keputusan individu untuk bertahan di organisasi. Individu dengan komitmen organisasi afektif memilih bertahan di organisasi karena ia menginginkannya (want to), sementara individu dengan komitmen organisasi kontinuans bertahan karena membutuhkannya (need to), dan individu dengan komitmen organisasi normatif bertahan karena merasa harus melakukannya (ought to).

Bagi organisasi, karyawan yang kompeten merupakan aset dan investasi berharga yang perlu dipertahankan. Dengan demikian, penting untuk menemukan faktor-faktor yang memengaruhi komitmen organisasi karyawan. Selama ini, penelitian komitmen organisasi pada Generasi Milenial lebih banyak diterapkan pada organisasi 
bisnis dan kesehatan (Filiana, 2016; Lub, Bijvank, Bal, Blomme, \& Schalk, 2012; Nusair, Parsa, \& Cobanoglu, 2011; Queiri \& Dwaikat, 2016), sementara pada organisasi pendidikan masih jarang dilakukan. Akan tetapi, pada kenyataannya komitmen organisasi di institusi pendidikan juga tak kalah pentingnya. Sebagaimana hasil penelitian yang diterapkan di organisasi perguruan tinggi, ditemukan bahwa komitmen organisasi pada dosen akan meningkatkan performa kinerjanya (Handoko, Setiawan, Surachman, \& Djumahir, 2010), kepuasan kerjanya (Odoch \& Nangoli, 2014) dan perilaku organisasi kewarganegaraannya (Özdem, 2012).

Dosen Generasi Milienial dihadapkan dengan berbagai tantangan dan tuntutan di tempat kerja. Tuntutan pertama adalah tuntutan untuk beradaptasi dengan dosen senior yang berasal dari generasi sebelumnya dan memiliki karakteristik yang berbeda dari mereka (Aruna \& Anitha, 2015). Selanjutnya, tuntutan kedua yang dihadapi oleh dosen Generasi Milenial adalah tuntutan penyesuaian dengan pekerjaan dosen yang beragam dan bervariasi. Cakupan tugas dosen dalam aspek pengajaran cukup bervariasi, dimulai dari merancang silabus pengajaran, memberikan pengajaran, serta menyusun dan mengevaluasi tugas mahasiswa (Seniati, 2006). Selain pengajaran, dalam tugas Tridharma Perguruan Tinggi, dosen juga memiliki tugas melaksanakan penelitian dan pengabdian pada masyarakat. Cakupan tugas penelitian juga cukup luas, dimulai dari menyusun proposal penelitian, menjalankan penelitian, hingga menyusun laporan akhir penelitian dan mempublikasikan hasil penelitian tersebut. Dosen juga memiliki tugas untuk menulis makalah dan buku serta membangun jaringan kerja (network) dalam suatu disiplin ilmu (Seniati, 2006).

Selain tugas pokok Tridharma Perguruan Tinggi tersebut, dosen juga memiliki tugas tambahan, misalnya memegang jabatan struktural dan menjadi anggota panitia kegiatan di fakultas maupun universitas (Seniati, 2006). Sementara itu, gaji dosen di Indonesia masih tergolong rendah dan jenjang karirnya cukup panjang. Hal-hal tersebut dapat memicu para dosen muda yang merupakan Generasi Milenial untuk memutuskan berhenti dari profesi dosen dan keluar dari perguruan tinggi. Dengan demikian, penemuan terhadap faktor yang memengaruhi komitmen organisasi pada dosen Generasi Milenial menjadi semakin penting untuk dilakukan. Sudah saatnya bagi Manajemen SDM di Perguruan Tinggi untuk menyadari dan memperhatikan adanya perbedaan generasi di lingkungan kerja mereka sehingga perlu menentukan intervensi yang tepat untuk masing-masing generasi tersebut (Bushardt, Young, \& Bari, 2018). Ditambah lagi, saat ini Generasi Milenial merupakan ujung tombak dari keberhasilan perguruan tinggi dan menjadi penerus dari dosen senior yang akan memasuki masa pensiun. Oleh karena itu, peneliti tertarik membangun penelitian mengenai komitmen organisasi di lingkungan institusi pendidikan tinggi dengan melibatkan dosen Gerenasi Milienial yang saat ini jumlahnya mencapai $45,6 \%$ dari jumlah populasi dosen di Indonesia (Herdiyanto, 2018).

Salah satu faktor yang diduga memengaruhi komitmen organisasi dosen Generasi Milenial adalah kepuasan kerja. Kepuasan kerja didefinisikan sebagai sikap yang merefleksikan bagaimana perasaan individu terhadap pekerjaannya, baik berdasarkan penilaian secara keseluruhan ataupun terhadap beberapa aspek yang ada dalam pekerjaan (Spector, 1997). Penelitian yang dilakukan oleh Nusair et al. (2011) menemukan bahwa ada hubungan positif yang signifikan antara kepuasan kerja dan komitmen organisasi pada Generasi Milenial. Penelitian serupa dengan hasil yang lebih spesifik juga pernah dilaporkan oleh Valaei dan Rezaei (2016) bahwa semua aspek dari kepuasan kerja memiliki hubungan positif 
yang signifikan dengan komitmen organisasi afektif dan normatif. Meskipun demikian, temuan-temuan mengenai hubungan antara kepuasan kerja dan komitmen organisasi masih kurang konsisten. Secara umum, ditemukan bahwa ada hubungan positif antara keduanya, akan tetapi untuk Generasi Milenial, pola hubungan tersebut masih bersifat anecdotal (Filiana, 2016). Oleh karena itu, penelitian lanjutan mengenai bentuk hubungan antara kepuasan kerja dan komitmen organisasi perlu ditinjau kembali.

Selain kepuasan kerja, faktor lain yang juga diduga memiliki pengaruh terhadap komitmen organisasi adalah komitmen profesi. Meskipun gaji dosen tergolong rendah, ternyata masih ada dosen muda yang tetap memilih bertahan dalam suatu perguruan tinggi karena memiliki komitmen terhadap profesinya sebagai dosen. Komitmen profesi diartikan sebagai keinginan individu untuk mengidentifikasikan dirinya terhadap sebuah profesi dan bertahan untuk menjadi anggota dalam profesi tersebut (Meyer, Allen, \& Smith, 1993). Sama halnya dengan komitmen organisasi, komitmen profesi juga memiliki tiga komponen yaitu afektif, kontinuans, dan normatif. Komitmen profesi afektif didefinisikan sebagai keterikatan individu secara emosional terhadap profesinya serta keterlibatan dan pengidentifikasian individu terhadap profesi tersebut. Kemudian komitmen profesi kontinuans diartikan sebagai kesadaran individu terkait perhitungan untung dan rugi yang akan diterimanya ketika keluar dari profesinya. Terakhir, komitmen profesi normatif mengacu pada perasaan kewajiban yang dirasakan oleh individu untuk tetap bertahan dalam suatu profesi (Meyer et al, 1993)

Penemuan terhadap pola hubungan antara komitmen profesi dan komitmen organisasi juga belum konsisten. Penelitian yang dilakukan oleh
Singh dan Gupta (2015) menemukan bahwa komitmen profesi memiliki hubungan yang negatif dengan keterlibatan kerja, komitmen organisasi, serta komitmen terhadap tim. Artinya, semakin tinggi komitmen profesi seseorang maka tingkat komitmennya terhadap organisasi tempat ia bekerja akan semakin rendah. Di sisi lain, penelitian yang dilakukan oleh Dwivedula dan Bredillet (2010) menunjukkan bahwa komitmen profesi yang dimiliki oleh seorang dapat meningkatkan komitmen organisasinya. Yousaf, Sanders, dan Abbas (2015) juga melakukan penelitian serupa dan melaporkan hasil yang lebih spesifik yaitu mereka menemukan bahwa ada korelasi yang positif antara komitmen profesi afektif dengan komitmen organisasi. Tidak konsistennya hasil penelitian terkait hubungan antara komitmen profesi dan komitmen organisasi membuat penelitian lanjutan perlu untuk dilakukan.

\section{Metode}

Responden dalam penelitian ini adalah 123 dosen dari 10 perguruan tinggi yang berada di Jakarta, Bali, dan Padang, baik dari Perguruan Tinggi Negeri (PTN) maupun dari Perguruan Tinggi Swasta (PTS). Pengambilan sampel dilakukan secara non-random sampling/non-probability sampling dengan menggunakan teknik sampling yaitu purposive sampling. Purposive sampling merupakan teknik sampling di mana sampel dipilih berdasarkan karakteristik yang telah ditentukan, yaitu: (1) dosen tetap di perguruan tinggi, baik yang berstatus Pegawai Negeri Sipil (PNS) maupun non-PNS; (2) lahir pada rentang tahun 1977-1994; dan (3) memiliki masa kerja minimal dua tahun di perguruan tinggi tempat mengajar sekarang.

Responden mengisi kuesioner berisikan tiga alat ukur. Ketiga alat ukur tersebut merupakan skala Likert dengan rentang pilihan dari 1 
(sangat tidak setuju) sampai 4 (sangat setuju). Alat ukur pertama adalah Skala Komitmen Organisasi untuk mengukur komitmen organisasi. Alat ukur ini merupakan hasil adaptasi oleh Seniati dan Yulianto (2010) berdasarkan alat ukur Organizational Commitment Scale (OCS) dari Allen \& Meyer (1996). Skala Komitmen Organisasi ini terdiri dari 21 item yang tersebar dalam tiga komponen, yaitu: afektif, kontinuans, dan normatif $(\alpha=0,89)$.

Kedua, survei kepuasan kerja yang berfungsi mengukur kepuasan kerja. Survei kepuasan kerja ini merupakan hasil adaptasi dari Seniati dan Yulianto (2010) berdasarkan alat ukur The Job Satisfaction Survey (JSS) dari Spector (1997). Alat ukur tersebut terdiri dari 21 item yang tersebar ke dalam tujuh aspek pekerjaan, yaitu pekerjaan itu sendiri, hubungan dengan atasan, rekan kerja, fasilitas kerja, imbalan, promosi, dan komunikasi $(\alpha=0,92)$. Terakhir, komitmen profesi diukur menggunakan Professional Commitment Scale (PCS) milik Allen \& Meyer (1996) yang sudah diadaptasi oleh peneliti dengan melakukan forward and back translation. Skala Komitmen Profesi terdiri dari 23 item yang tersebar dalam tiga komponen, yaitu afektif, kontinuans, dan normatif $(\alpha=0,78)$.

Data yang telah dikumpulkan kemudian diolah secara kuantitatif dengan menggunakan program SPSS. Proses analisis data dimulai dari uji statistik deskriptif untuk melihat tingkat komitmen profesi, kepuasan kerja, dan komitmen organisasi pada dosen Generasi Milenial.
Selanjutnya, uji korelasi dilakukan untuk melihat signifikansi hubungan antara variabel-variabel yang ada dalam penelitian ini. Kemudian, uji regresi juga dilakukan untuk melihat pengaruh dari kepuasan kerja dan komitmen profesi terhadap komitmen organisasi pada dosen Generasi Milenial. Selain itu, dilakukan uji regresi berganda untuk melihat aspek mana dari kepuasan kerja serta komponen apa dari komitmen profesi yang memberikan sumbangan paling besar terhadap tingkat komitmen organisasi pada dosen Generasi Milenial.

\section{Hasil}

Responden dalam penelitian ini terdiri dari $34,1 \%$ laki-laki dan 65,9\% perempuan. Tingkat pendidikan responden umumnya adalah S2 yaitu sebanyak $92,7 \%$ dan sisanya 7,3\% berpendidikan terakhir S3. Berdasarkan jabatan fungsional, mayoritas responden merupakan asisten ahli (61\%) dan sisanya adalah lektor (26\%) dan lektor kepala $(1,6 \%)$. Responden yang berstatus sebagai dosen PNS ada sebanyak 52,8\% dan sisanya 46,3\% merupakan dosen tetap Non-PNS. Hasil uji statistik deskriptif guna melihat tingkat komitmen profesi, kepuasan kerja, dan komitmen organisasi pada dosen Generasi Milenial, dan nilai koefisien reliabilitas dari masingmasing alat ukur dapat dilihat pada Tabel 1.

Analisis statistik deskriptif menunjukkan bahwa skor rata-rata kepuasan kerja adalah 3,01; skor rata-rata komitmen profesi adalah 2,83; dan

Tabel 1.

Hasil Uji Statistik Deskriptif dan Koefisien Reliabilitas Alat Ukur

\begin{tabular}{lccc}
\hline Variabel & Mean & $S D$ & $\alpha$ \\
\hline Komitmen Organisasi & 2,82 & 0,43 & 0,89 \\
Kepuasan Kerja & 3,01 & 0,28 & 0,92 \\
Komitmen Profesi & 2,83 & 0,42 & 0,78 \\
\hline
\end{tabular}

Mean: Rata-rata skor; SD: Standar Deviasi; $\alpha$ : koefisien reliabilitas (Alpha Cronbach) 
Tabel 2.

Hasil Uji Korelasi antar Variabel

\begin{tabular}{lccc}
\hline Variabel & 1 & $R$ & 3 \\
\hline Komitmen Organisasi & & 2 & \\
Kepuasan Kerja & $0,59^{* *}$ & & \\
Komitmen Profesi & $0,62^{* *}$ & $0,39^{* *}$ & \\
\hline
\end{tabular}

$* * p<0,01 ; r$ : koefisien korelasi

skor rata-rata komitmen organisasi adalah 2,82 (dari rentang 1-4). Hal ini berarti bahwa tingkat kepuasan kerja dosen Generasi Milenial sudah lebih baik dibandingkan tingkat komitmen profesi dan komitmen organisasinya yang masih tergolong rendah. Dengan demikian, perlu usaha lebih besar dari pihak Manajemen SDM di Perguruan Tinggi untuk meningkatkan komitmen organisasi dan komitmen profesi pada dosen Generasi Milenial.

Analisis selanjutnya adalah uji korelasi untuk melihat hubungan antara variabel kepuasan kerja dengan komitmen organisasi serta hubungan antara variabel komitmen profesi dengan komitmen organisasi. Hasil uji korelasi tersebut dapat dilihat pada Tabel 2.

Hasil uji korelasi menunjukkan bahwa komitmen organisasi memiliki korelasi positif yang signifikan dengan kepuasan kerja $(r=$
0,59; $p<0,01)$ dan juga dengan komitmen profesi $(r=0,62 ; p<0,01)$. Hal ini berarti bahwa peningkatan skor kepuasan kerja dan komitmen profesi akan diikuti dengan peningkatan skor komitmen organisasi dari dosen Generasi Milenial. Begitu juga sebaliknya, penurunan dari skor kepuasan kerja dan komitmen profesi akan diikuti dengan penurunan pada skor komitmen organisasi.

Uji regresi kemudian dilakukan untuk melihat pengaruh dari kepuasan kerja dan komitmen profesi terhadap komitmen organisasi dosen Generasi Milenial. Hasil uji regresi menunjukkan bahwa terdapat pengaruh positif yang signifikan dari kepuasan kerja terhadap komitmen organisasi $(\beta=0,42 ; p<0,01)$. Selain itu ditemukan bahwa terdapat pengaruh positif yang signifikan dari komitmen profesi terhadap komitmen organisasi $(\beta=0,46 ; p<0,01)$.

Tabel 3.

Hasil Uji Regresi Berganda

\begin{tabular}{lcc}
\hline $\begin{array}{l}\text { Aspek Kepuasan Kerja dan } \\
\text { Komponen Komitmen Profesi }\end{array}$ & $B$ & $P$ \\
\hline $\begin{array}{l}\text { Aspek Kepuasan Kerja } \\
\text { Pekerjaan }\end{array}$ & 0,052 & 0,531 \\
$\quad$ Atasan & $0,218^{*}$ & 0,036 \\
Rekan & 0,040 & 0,684 \\
Fasilitas & 0,032 & 0,709 \\
Imbalan & 0,053 & 0,591 \\
$\quad$ Promosi & 0,142 & 0,093 \\
$\quad$ Komunikasi & 0,058 & 0,626 \\
\hline Komponen Komitmen Profesi & & \\
$\quad$ Afektif & $-0,003$ & 0,969 \\
$\quad$ Kontinuans & $0,281^{* *}$ & 0,000 \\
$\quad$ Normatif & $0,287^{* *}$ & 0,002 \\
\hline
\end{tabular}

${ }^{*} p<0,05 ;{ }^{*} p<0,01 ; \beta$ : koefisien regresi; $p$ : signifikansi 
Selanjutnya, dilakukan uji regresi berganda untuk melihat manakah dari aspek kepuasan kerja serta komponen komitmen profesi yang paling berpengaruh terhadap tingkat komitmen organisasi pada dosen Generasi Milenial. Hasil uji regresi berganda dapat dilihat pada Tabel 3 .

Tabel 3 menunjukkan bahwa aspek dari kepuasan kerja yang memiliki pengaruh positif yang signifikan terhadap tingkat komitmen organisasi dosen Generasi Milenial adalah kepuasan terhadap atasan $(\beta=0,218 ; p<0,05)$. Hal ini berarti bahwa kepuasan dosen Generasi Milenial terhadap atasannya akan meningkatkan komitmen organisasi yang dimilikinya.

Selanjutnya, pada Tabel 3 juga terlihat bahwa komponen dari komitmen profesi yang secara signifikan berpengaruh positif terhadap tingkat komitmen organisasi dosen Generasi Milenial adalah komitmen profesi kontinuans $(\beta=0,281 ; p$ $<0,01)$ dan normatif $(\beta=0,287 ; p<0,01)$. Artinya, ketika dosen Generasi Milenial memiliki komitmen profesi kontinuans dan normatif yang tinggi maka hal ini juga akan meningkatkan komitmen organisasi yang dimilikinya. Di sisi lain, komitmen profesi afektif ditemukan tidak memiliki pengaruh yang signifikan terhadap tingkat komitmen organisasi dosen Generasi Milenial.

\section{Diskusi}

Setelah dilakukan analisis data, dapat disimpulkan bahwa pertanyaan dalam penelitian ini berhasil dijawab. Hasil penelitian menunjukkan bahwa terdapat pengaruh positif yang signifikan dari kepuasan kerja terhadap komitmen organisasi yang dimiliki oleh dosen Generasi Milenial. Generasi Milenial memang terkenal sebagai generasi yang memiliki tingkat toleransi yang sangat rendah terhadap ketidak-sesuaian antara apa yang mereka harapkan dengan apa yang mereka terima dari organisasi. Mereka akan memilih mengundurkan diri dari organisasi saat pekerjaannya tidak sesuai dengan harapan dan tidak mampu memenuhi kebutuhan (Kim et al., 2009). Dengan kata lain, semakin puas dengan aspek-aspek dalam pekerjaan, maka semakin mereka akan berkomitmen terhadap organisasinya. Penelitian ini sejalan dengan hasil penelitian yang dilakukan oleh Teng, Lotus Shyu, \& Chang (2007) yang menemukan bahwa kepuasan kerja yang dirasakan oleh seseorang akan menentukan keputusannya untuk bertahan atau keluar dari organisasi.

Temuan selanjutnya adalah terdapat pengaruh positif yang signifikan dari komitmen profesi terhadap komitmen organisasi pada dosen Generasi Milenial. Penelitian-penelitian terdahulu juga mendukung hasil ini di mana sebelumnya ditemukan bahwa interaksi antara komitmen profesi dan komitmen organisasi adalah positif (Dwivedula \& Bredillet, 2010). Dengan kata lain, komitmen profesi pada seseorang dapat meningkatkan komitmen organisasi yang dimilikinya. Dengan memutuskan bertahan pada profesi dosen (memiliki komitmen profesi yang tinggi), maka pilihan alternatif pekerjaan lain yang dimiliki individu akan menjadi berkurang, sehingga kemudian individu akan lebih memilih bertahan pada perguruan tinggi sebagai organisasi tempat mereka bekerja (komitmen organisasi tinggi). Apabila perguruan tinggi mampu memberikan kesempatan dan memfasilitasi dosen Generasi Milenial dalam melakukan pengembangan karir sebagai dosen, maka dosen Generasi Milenial akan cenderung memilih bertahan di organisasi tersebut (Aruna \& Anitha, 2015).

Akan tetapi, ketika diterapkan pada profesi yang berbeda, maka hasil yang didapatkan bisa menjadi berbeda dengan temuan dari penelitian ini. Seperti halnya dalam penelitian terdahulu yang dilakukan oleh Cho dan Huang (2012) yang 
melibatkan profesi di bidang teknologi informasi (TI). Penelitian tersebut menemukan bahwa hubungan antara komitmen organisasi dan komitmen profesi adalah negatif. Karyawan di bidang teknologi informasi (TI) cenderung memiliki keinginan untuk meninggalkan organisasi demi meningkatkan profesionalitasnya. Ketika mereka memiliki komitmen profesi yang tinggi, mereka akan cenderung untuk memilih berpindah-pindah dari satu organisasi ke organisasi lain dalam rangka mengembangkan dan memperkaya pengalamannya di bidang teknologi informasi (TI). Sehingga kemudian semakin tinggi komitmen profesinya maka komitmen organisasinya menjadi semakin rendah. Hal ini menunjukkan bahwa masing-masing profesi memiliki karakteristik pekerjaan yang berbedabeda sehingga kemudian bisa menghasilkan hasil penelitian yang berbeda juga.

Saat dilakukan uji regresi berganda ditemukan bahwa aspek dari kepuasan kerja yang memiliki pengaruh positif yang signifikan terhadap komitmen organisasi dosen Generasi Milenial adalah kepuasan terhadap atasan di mana atasan yang dimaksud dalam penelitian ini adalah pimpinan fakultas. Ketika pimpinan fakultas mampu memberikan otonomi kepada para dosen dalam bekerja dibandingkan kondisi di mana mereka harus diberikan pengawasan yang ketat, maka dosen Generasi Milenial akan lebih merasa memiliki keterikatan kerja. Sebagaimana yang ditemukan dalam penelitian yang dilakukan oleh Forastero, Sjabadhyni, \& Mustika (2018) bahwa terdapat pengaruh yang signifikan dari job autonomy terhadap keterikatan kerja pada Generasi Milenial. Selain itu, ketika pimpinan mampu memberikan kebebasan pada dosen dalam mencapai kehidupan kerja dan kehidupan pribadi yang seimbang, maka kepuasan hubungan dengan atasan pada dosen Generasi Milenial juga akan meningkat (Smola \& Sutton, 2002). Begitu juga ketika dosen Generasi Milenial me- rasa mendapat pengakuan atas apa yang mereka lakukan, kemungkinan besar mereka akan memiliki komitmen organisasi yang tinggi karena mereka merasa dihargai. Hal ini karena salah satu karakteristik dari Generasi Milenial adalah mereka cenderung mencari umpan balik dan saran dari atasan mereka mengenai kinerjanya (Salahudin et al., 2016). Semakin pihak pimpinan fakultas mampu memenuhi harapan tersebut maka tingkat komitmen organisasi dosen Generasi Milenial juga akan semakin meningkat.

Benson dan Brown (2011) pernah melakukan penelitian untuk membandingkan perbedaan antara Generasi Baby Boom dan Generasi X dalam hal hubungan antara kepuasan kerja dan komitmen organisasinya. Penelitian tersebut menemukan bahwa aspek dari kepuasan kerja yang memengaruhi Generasi Baby Boom untuk bertahan dalam organisasi adalah hubungan dengan atasan, sementara pada Generasi X adalah hubungan dengan rekan kerja. Hal ini menunjukkan bahwa masing-masing generasi memiliki ciri khas tersendiri karena mereka lahir pada tahun yang berbeda sehingga mengalami kondisi sejarah, politik, budaya, ekonomi, dan teknologi yang berbeda-beda pada masanya dan akhirnya mereka menganut nilai, tujuan, dan sikap kerja yang berbeda-beda pula (Benson \& Brown, 2011; Duvendack, 2010). Hal ini didukung dengan penelitian (Agrawal, 2017) yang menemukan bahwa ada perbedaan yang signifikan dalam hal kepribadian dan faktor yang memengaruhi komitmen organisasi antara Generasi Milenial dan Generasi X. Generasi Milenial cenderung lebih menyukai hubungan sosial, lebih percaya diri, dan lebih sensitif dibandingkan Generasi X. Selain itu, juga ditemukan bahwa komitmen organisasi pada Generasi Milenial lebih dipengaruhi oleh faktor organisasi seperti keseimbangan kehidupan pribadi dan kerja, dukungan organisasi, dan gaya kepemimpinan; sementara pada Generasi X lebih dipengaruhi 
oleh faktor individu seperti kepribadian (Agrawal, 2017).

Selanjutnya, penelitian ini juga menemukan bahwa komponen dari komitmen profesi yang memiliki pengaruh signifikan terhadap tingkat komitmen organisasi dosen Generasi Milenial adalah komitmen profesi kontinuans dan komitmen profesi normatif, sementara pada komitmen profesi afektif tidak berlaku demikian. Hal ini berkaitan erat dengan karakteristik Generasi Milenial di mana perhitungan mengenai untung dan rugi yang mereka dapatkan dari mempertahankan profesinya sebagai dosen akan menjadi tolak ukur yang akan menentukan apakah mereka akan tetap bertahan di perguruan tinggi tempat mereka mengajar atau tidak. Adanya perasaan tanggung jawab untuk berbagi ilmu pengetahuan kepada orang lain juga menjadi alasan pada Generasi Milenial untuk bertahan di profesi dosen dan tetap menjadi anggota di perguruan tinggi tempat mereka mengajar.

Penelitian ini hanya melibatkan dosen Generasi Milenial di Kota Padang, Jakarta, dan Bali sehingga memiliki keterbatasan dalam generalisasi. Diharapkan penelitian lanjutan dapat dilakukan dengan melibatkan perguruan tinggi dari kota-kota lainnya di Indonesia sehingga bisa merepresentasikan kondisi dosen Generasi Milienial di Indonesia secara keseluruhan. Selain itu, penelitian ini bersifat cross-sectional, pengambilan data hanya dilakukan satu kali sehingga pembuktian dari adanya pengaruh dari suatu variabel terhadap variabel lain belum begitu kuat. Penelitian lanjutan bisa dilakukan dengan desain longitudinal study untuk memperkuat hasil temuan. Terakhir, penelitian lanjutan dapat dilakukan dengan melibatkan variabel-variabel lain yang diasumsikan juga memiliki pengaruh signifikan terhadap komitmen organisasi pada Generasi Milenial, seperti keadilan organisasi
(George \& Wallio, 2017) atau gaya kepemimpinan (Jauhar, Ting, \& Rahim, 2017).

\section{Simpulan}

Penelitian ini menunjukkan bahwa terdapat pengaruh positif yang signifikan dari kepuasan kerja dan komitmen profesi terhadap komitmen organisasi dosen Generasi Milenial. Secara lebih spesifik, ditemukan bahwa kepuasan terhadap atasan, komitmen profesi kontinuans, dan komitmen profesi normatif memiliki pengaruh positif yang signifikan terhadap komitmen organisasi dosen Generasi Milenial. Penelitian ini memiliki implikasi bagi perguruan tinggi dalam hal manajemen SDM yang ada di dalamnya, khususnya untuk para dosen Generasi Milenial. Perguruan tinggi harus mampu mempertimbangkan dalam memilih pendekatan yang berbeda ketika ingin meningkatkan komitmen organisasi pada masingmasing generasi, khususnya dosen Generasi Milenial yang akan menjadi penerus generasigenerasi sebelumnya.

\section{Saran}

Penelitian ini masih memiliki kekurangan karena tidak melihat pengaruh dari kepuasan kerja dan komitmen profesi untuk masingmasing komponen dari komitmen organisasi (afektif, kontinuans, dan normatif), melainkan hanya melihat komitmen organisasi secara keseluruhan. Ketika ketiga komponen komitmen tersebut sama-sama dipertimbangkan maka peluang untuk mendapatkan pemahaman yang lebih menyeluruh akan semakin besar (Meyer \& Allen, 1990). Dengan demikian, saran untuk penelitian selanjutnya adalah menjadikan ketiga komponen dari komitmen organisasi, yaitu afektif, kontinuans, dan normatif, sebagai variabel terikatnya. Selain itu, penelitian selanjutnya bisa diperluas dengan melibatkan profesi selain dosen dan generasi selain milenial. [ ] 


\section{Daftar Pustaka}

Agrawal, S. (2017). Personality traits and organisational commitment of Gen X and Gen Y employee. Journal of Organisation \& Human Behaviour, 6(1-2), 10-17. Retrieved from http://www.publishingindia.com/johb/48/personality-traits-and-organisationalcommitment-of-gen-x-and-gen-y-employees/577/4085/

Allen, N. J., \& Meyer, J. P. (1996). Affective, continuance, and normative commitment to the organization: An examination of construct validity. Journal of Vocational Behavior, 49(3), 252-276. https://doi.org/10.1006/JVBE.1996.0043

Angeline, T. (2011). Managing generational diversity at the workplace: Expectations and perceptions of different generations of employees. African Journal of Business Management, 5(2), 249-255. https://doi.org/10.5897/AJBM10.335

Aruna, M., \& Anitha, J. (2015). Employee retention enablers: Generation Y employees. SCMS Journal of Indian Management, 12(3), 94-103.

Benson, J., \& Brown, M. (2011). Generations at work: Are there differences and do they matter? The International Journal of Human Resource Management, 22(9), 1843-1865. https://doi.org/ 10.1080/09585192.2011.573966

Bushardt, S. C., Young, M., \& Bari, A. (2018). Transitioning to management: Challenges and opportunities for the millenial generation. Journal of Business Diversity, 18(1), 9-16.

Cho, V., \& Huang, X. (2012). Professional commitment, organizational commitment, and the intention to leave for professional advancement: An empirical study on IT professionals. Information Technology and People, 25(1), 31-54. https://doi.org/10.1108/09593841211204335

Duvendack, C. M. (2010). Correlation of work-life balance decisions of different generations of physicians. Minnesota: Capella University.

Dwivedula, R., \& Bredillet, C. N. (2010). The relationship between organizational and professional commitment in the case of project workers: Implications for project management. Project Management Journal, 41(4), 79-88. https://doi.org/10.1002/pmj.20196

Filiana, G. S. (2016). Job satisfaction and organizational commitment among Generation-Y: The impact of intrinsic and extrinsic factors on affective, continuance, and normative commitment. Denmark: Business and Social Science, Aarhus University.

Forastero, A., Sjabadhyni, B., \& Mustika, M. D. (2018). What millennials want: How to optimize their work. Psikohumaniora: Jurnal Penelitian Psikologi, 3(1), 1-16. https://doi.org/10.21580/ pjpp.v3i1.2489

George, J., \& Wallio, S. (2017). Organizational justice and millennial turnover in public accounting. Employee Relations, 39(1), 112-126. https://doi.org/10.1108/ER-11-2015-0208

Handoko, Y., Setiawan, M., Surachman, S., \& Djumahir, D. (2010). Organizational culture, job satisfaction, organizational commitment, the effect on lecturer performance. International Journal of Business and Management Invention, 2(12), 21-30.

Hawkins, D. I., \& Mothersbaugh, D. L. (2010). Consumer behavior: Building marketing strategy (13th ed.). Boston: McGraw-Hill Book Company Inc.

Herdiyanto, F. (2018). Buku statistik pendidikan tinggi 2017. Jakarta: Forlap Dikti. 
Jauhar, J., Ting, C. S., \& Rahim, N. F. A. (2017). The impact of reward and transformational leadership on the intention to quit of Generation Y employees in oil and gas industry: Moderating role of job satisfaction. Global Business and Management Research: An International Journal, 9(4), 426-442.

Kim, H. J., Knight, D. K., \& Crutsinger, C. (2009). Generation Y employees' retail work experience: The mediating effect of job characteristics. Journal of Business Research, 62(5), 548-556. https://doi.org/10.1016/j.jbusres.2008.06.014

Lub, X., Bijvank, M. N., Bal, P. M., Blomme, R., \& Schalk, R. (2012). Different or alike?: Exploring the psychological contract and commitment of different generations of hospitality workers. International Journal of Contemporary Hospitality Management, 24(4), 553-573. https://doi.org/10.1108/09596111211226824

Meyer, J. P., \& Allen, N. J. (1990). The measurement and antecedent of affective, continuance and normative commitment to the organization.Journal of Occupational Psychology, 63(1), 1-18.

Meyer, J. P., \& Allen, N. J. (1991). A three-component conceptualization of organizational commitment. Human Resource Management Review, 1(1), 61-89. https://doi.org/10.1016/10534822(91)90011-Z

Meyer, J. P., \& Allen, N. J. (1997). Commitment in the workplace: Theory, research, and application. Thousand Oaks, CA: SAGE Publications, Inc. https://doi.org/10.4135/9781452231556

Meyer, J. P., Allen, N. J., \& Smith, C. A. (1993). Commitment to organizations and occupations: Extention and test of a three-component conceptualization. Journal of Applied Psychology, 78(4), 538-551. https://doi.org/10.1037/0021-9010.78.4.538

Nusair, K. K., Parsa, H. G., \& Cobanoglu, C. (2011). Building a model of commitment for Generation Y: An empirical study on e-travel retailers. Tourism Management, 32(4), 833-843. https://doi.org/ 10.1016/j.tourman.2010.07.008

Odoch, H., \& Nangoli, S. (2014). The effect of organizational commitment on job satisfaction in Uganda Colleges of Commerce. Issues in Business Management and Economics, 2(10), 165-171.

Özdem, G. (2012). The relationship between the organizational citizenship behaviors and the organizational and professional commitments of secondary school teacher. Journal of Global Strategic Management, 2(6), 47-47. https://doi.org/10.20460/JGSM.2012615773

Queiri, A., \& Dwaikat, N. (2016). Factors affecting Generation Y employees' intention to quit in Malaysian's business process outsourcing sector. Journal of Sustainable Development, 9(2), 78. https://doi.org/10.5539/jsd.v9n2p78

Salahudin, S. N. bin, Alwi, M. N. R. bin, Baharuddin, S. S. bt, \& Abd Samad, N. I. bt. (2016). Generation Y: Organizational commitment and turnover intention. In The European Proceedings of Social \& Behavioural Sciences (pp. 448-456). https://doi.org/10.15405/epsbs.2016.11.02.41

Seniati, A. N. L., \& Yulianto, A. (2010). Pengaruh faktor pribadi dan faktor lingkungan terhadap komitmen profesi dan komitmen organisasi pada dosen perguruan tinggi Jakarta. Laporan penelitian. Depok: Universitas Indonesia.

Seniati, L. (2006). Pengaruh masa kerja, trait kepribadian, kepuasan kerja, dan iklim psikologis terhadap komitmen dosen pada Universitas Indonesia. Makara: Human Behavior Studies in Asia, 10(2). https://doi.org/10.7454/MSSH

Sheahan, P. (2009). Generation Y in Asia. Sydney: The University of Sydney.

Smola, K. W., \& Sutton, C. D. (2002). Generational differences: Revisiting generational work values for the new millennium. Journal of Organizational Behavior, 23(4), 363-382. https://doi.org/ 10.1002/job.147 
Spector, P. E. (1997). Job satisfaction: Application, assessment, cause, and consequences. Thousand Oaks, CA.: Sage Publications. Retrieved from https://www.worldcat.org/title/job-satisfactionapplication-assessment-cause-and-consequences/oclc/36301511

Teng, C.-I., Lotus Shyu, Y.-I., \& Chang, H.-Y. (2007). Moderating effects of professional commitment on hospital nurses in Taiwan. Journal of Professional Nursing: Official Journal of the American Association of Colleges of Nursing, 23(1), 47-54. https://doi.org/10.1016/ j.profnurs.2006.10.002

Trapero, F. A., Villa-Castaño, L. E., Parra, J. C. V., \& García, J. D. la G. (2017). Differences on self-perception of organizational pride and loyalty in Millennial \& Generation X, considering gender and seniority variables. BEH: Business and Economic Horizons, 13(2), 270-286. https://doi.org/ 10.15208/beh.2017.20

Valaei, N., \& Rezaei, S. (2016). Job satisfaction and organizational commitment: An empirical investigation among ICT-SMEs. Management Research Review, 39(12), 1663-1694. https://doi.org/10.1108/MRR-09-2015-0216

Yousaf, A., Sanders, K., \& Abbas, Q. (2015). Organizational/occupational commitment and organizational/occupational turnover intentions: A happy marriage? Personnel Review, 44(4), 470-491. https://doi.org/10.1108/PR-12-2012-0203 